241

Received: September 29, 2017

Accepted: December 7, 2017
Macedonian Journal of Animal Science, Vol. 7, No. 1-2, pp. 89-95 (2017)

ISSN $1857-6907$

e-ISSN $1857-7709$

UDC: $636.5(497.7)$

Original scientific paper

\title{
PROBLEMS AND PERSPECTIVES OF POULTRY PRODUCTION IN THE REPUBLIC OF MACEDONIA
}

\author{
Nedeljka Nikolova ${ }^{1}$, Dragoslav Kocevski ${ }^{2}$ \\ ${ }^{1}$ Institute of Animal Science, Skopje, "Ss. Cyril and Methodius" University in Skopje, \\ Blvd. Ilinden 92a, Skopje, Republic of Macedonia \\ ${ }^{2}$ Faculty of Agricultural Sciences and Food, "Ss. Cyril and Methodius" University in Skopje, \\ Blvd. Aleksandar Makedonski bb, Skopje, Republic of Macedonia \\ nikolova13@gmail.com
}

\begin{abstract}
The paper presents in short the situation, problems and perspectives of poultry production in the Republic of Macedonia. It has been found that in the last ten years there is a continuous stagnation of poultry breeding, and the reasons for that are: generally very poor economic conditions, the very long period of transition and privatization, and the low living standard. Once a state with high-developed poultry production within the former Yugoslavia when it supplied 30\% of the Yugoslav needs for eggs and exported live material (chicks one-day old and pullets), Macedonia today experiences a rapid fall in the production of eggs, while the production of poultry meat as if doesn't exist at all. The needs of the population for chicken meat are satisfied in $94 \%$ through import of frozen meat from many countries in the world, which do not meet the required quality standards. A complete revitalization of poultry production is necessary through a series of measures outlined in the paper. Their implementation will contribute to overcoming all the objective and subjective difficulties because the Republic of Macedonia has the necessary resources for the development of poultry breeding which in the future would provide sufficient products for the domestic population, but also for export, especially of products from alternative systems of poultry farming.
\end{abstract}

Key words: poultry production in the Republic of Macedonia; problems; present condition; development measures

\section{ПРОБЛЕМИ И ПЕРСПЕКТИВИ НА ЖИВИНАРСТВОТО ВО РЕПУБЛИКА МАКЕДОНИЈА}

Во трудот накратко е презентирана состојбата, проблемите и перспективата на живинарското производство во Република Македонија. Констатирано е дека во последните десет години постои континуирана стагнација на живинарството, а како едни од причините се наведуваат: генерално многу лошата економска состојба, долгиот транзициски период и лошата приватизација, како и опаѓањето на животниот стандард. Од една состојба на високо развиено живинарско производство во секторот производство на јајца во времето на бивша СФРЈ, кога снабдуваше $30 \%$ од нејзините потреби и реализираше извоз на жив материјал (еднодневни пилиња и јарки), Република Македонија денес се соочува со рапидно намалување на производството на јајца, додека производство на живинско месо како воопшто и да не постои. Потребите на населението од пилешко месо се задоволуваат преку $94 \%$ увоз на замрзнато месо од повеќе земји во светот, кое не го задоволува потребниот квалитет. Неопходна е целосна ревитализација на живинарското производство преку низа мерки кои се наведени во трудот. Нивното спроведување ќе придонесе за совладување на сите објективни и субјективни тешкотии, бидејќи Република Македонија располага со неопходните ресурси за развој на живинарството кое во иднина би обезбедувало доволно производи за домашното население, но особено и за извоз на производи од алтернативните системи на одгледување живина.

Клучни зборо;ви: живинарско производство во Република Македонија; моментална состојба; мерки за развој

\section{INTRODUCTION}

The modern poultry production, thanks to the fast reproduction, the possibility for ambient control and adaptation, efficient health prevention, the industrial ways of production and use of poultry feed, the quality and the large demand for these products, shows constant growth in both developed and unde- 
veloped countries. In these countries poultry meat participates with about $25 \%$ in the total production and consumption of meat.

Poultry breeding in the Republic of Macedonia is primarily oriented towards production of eggs for final consumption, and as a secondary production the production of poultry meat. The largest part of the poultry reared are laying hens, while a smaller part are pullets for fattening (broilers), turkeys, ducks, geese and so on. The number of reared hens shows a trend of steady decrease year by year, whereas the number of eggs obtained from an average hen doesn't follow this trend since in Macedonia, for a longer period now, are reared high-quality hybrids acquired from renowned selection centers abroad.

In the last decade, with the transformation of the big state-owned agricultural complexes and their reduction, the owners' structure of the farms for breeding animals hasn't changed a lot, the same reaming further as private-owned small economies. Namely, today's poultry producers in Macedonia are mainly small, individually-owned farms whose production is intended mainly for their own sustenance, a certain number of farms are commercially oriented with a trend for increasing the production, and the rest are a small number of large farms whose number rapidly decreases. The small farms in a large extent feature a low level of modernization, poor sanitary conditions and insufficiently implemented rules for animals' well-being, whereupon all these factors will be the main reason for insufficient increase of their competitiveness on the market and difficulties in penetration into EU markets.

What are the reasons for such a rapid reduction of the overall poultry production? Here are some of them: decrease of the demand for products of animal origin because of the fall in the living standard, the very long period of transition and privatization, the reduction of the domestic market, non-conformation with the EU standards which is a limiting factor for export to European markets, incompetitiveness on the foreign markets because of the high production costs, the technical obsolescence of the production facilities, the rather limited range of endproducts, and the small institutional support by the state in certain poultry production segments. To all this we must add the problems with the acquisition of parental couples, as well as the difficulties with the import of certain components and additives for the feed, and of vaccines and medicaments. For all these reasons the consumption of poultry meat per capita fell from the record $13.2 \mathrm{~kg}$ in 1988 to less than $6 \mathrm{~kg}$ in 1994, and the consumption of eggs from 230 pieces in 1989 to 109 pieces in 1995 (Supić et al., [8]; FAOSTAT, 2010 [3]).

There are quite big problems in the poultry production, especially evident in the broiler production, i.e. in the production of chicken meat, so that we can freely say it almost doesn't exist at the moment, and the consumers' needs are satisfied through import of meat from many countries in the world.

\section{POULTRY PRODUCTION IN THE PAST}

In the past, Macedonia was a part of a much bigger country with nearly 23 million people, where it was satisfying $30 \%$ of the population's needs for eggs. Also, with the two big reproduction centers for light and heavy materials, in Skopje and Kriva Palanka, it was satisfying the needs for one-day old female chicks and pullets of all the domestic poultry farms, while a substantial part of the poultry products were exported abroad (in the neighboring countries, other European countries, Near-East countries, etc.).

When we speak about the market potential of the states of ex-Yugoslavia, except Slovenia, the total poultry meat production per year amounted to 171,000 tons, while the consumption per capita was 11-12 kilograms. At the same time, all these states together imported 41,000 tons and exported 3,000 tons per year.

The production of poultry meat and eggs in $\mathrm{R}$. Macedonia, in the previous period, was based mainly on organization of the production in large, specialized farms in ownership of the state, also in family-owned farms with much lesser capacity (a few hundred or a few thousand laying hens or broilers in one production cycle) and in small-scale production in farmyards (the so-called extensive production). This production was generally a very profitable business for those producers who observed the main postulates for intensive production of poultry.

Just before the dissolution of ex-SFRY the poultry producers were organized in that way so the large-scale production of poultry meat was done in Slovenia and Croatia, the large-scale production of eggs in Bosnia and Hercegovina and in Macedonia, while in Vojvodina and Serbia prevailed the combination of both types. After the dissolution of SFRY, the poultry producers in Macedonia are organized in the Group for Poultry at the Economic Chamber of 
Macedonia, whose purpose is to represent the interests of poultry breeders in front of the government's agencies and institutions, to create contacts with kindred companies from the countries in the region, to find out possibilities for joint acquisition of raw materials, intermediate products and equipment as well as for joint marketing on third-party markets, joint representation on business fairs and forums, and joint follow-up of EU rules and regulations and conformation with these. How much the Group has succeeded in solving the pressing problems of poultry producers is a question that needs special elaboration, and we won't discuss it here.

\section{THE CURRENT SITUATION AND PROBLEMS IN THE POULTRY PRODUCTION IN THE REPUBLIC OF MACEDONIA}

\section{Production of table eggs}

The number of reared poultry (broilers, turkeys, ducks, geese and other) in some years in the recent past according to the data provided by the State Agency of Statistics [7] is the Table 1:
The total number of poultry of some 2,800,000 birds in 2001, decreased to approximately $1,800,000$ birds in 2016, which is a drop of some $36 \%$, while the same is much more dramatic compared with the number in 1991 when approximately $4,500,000$ birds were reared and is equal to $60 \%$.

The total number of laying hens has a steady trend of decrease which is equal to $20 \%$ in the last 10 years (Table 2 ). The data in the table show that the number of laying hens in the individual sector is on the average bigger than the number in the business sector, being in decrease till 2013, afterwards taking an upward trend all to the last year (2016). Nevertheless, in the period 2011-2014 this number was bigger in the business sector.

The total number of produced eggs continuously decreases from 2007 onwards, equalling some $55 \%$. Much more unstable is the production in the business sector than in the individual. The number of eggs produced in this sector notes a rapid decrease in the recent years, and the reasons for that are: unstable domestic market, uncontrolled import of cheaper eggs, much bigger market supply of eggs than the demand in the summer months, small capacity of the plants for processing eggs, and so on.

Table 1

Total number of poultry reared in the Republic of Macedonia

\begin{tabular}{cccccccc}
\hline \hline \multirow{2}{*}{ Poultry } & 2001 & 2006 & 2008 & 2010 & 2012 & 2014 & 2016 \\
\hline \hline & 2749637 & 2585328 & 2226055 & 1994852 & 1776297 & 1939879 & 1865769 \\
\hline \hline
\end{tabular}

Table 2

Number of layers and eggs by years in the business and individual sectors

\begin{tabular}{ccccccc}
\hline \hline Year & $\begin{array}{c}\text { Total number of } \\
\text { layers }\end{array}$ & $\begin{array}{c}\text { Business } \\
\text { sector }\end{array}$ & $\begin{array}{c}\text { Individual } \\
\text { sector }\end{array}$ & $\begin{array}{c}\text { Total number of } \\
\text { eggs }(\times 1000)\end{array}$ & $\begin{array}{c}\text { Business } \\
\text { sector }\end{array}$ & $\begin{array}{c}\text { Individual } \\
\text { sector }\end{array}$ \\
\hline 2007 & 1719587 & 706754 & 1012833 & 321146 & 178538 & 142608 \\
2008 & 1668386 & 705259 & 963127 & 276398 & 157386 & 119012 \\
2009 & 1532514 & 644316 & 888198 & 274043 & 164430 & 109613 \\
2010 & 1688381 & 706960 & 981421 & 335820 & 171015 & 164805 \\
2011 & 1493672 & 953657 & 540015 & 255744 & 130178 & 125566 \\
2012 & 1429632 & 921932 & 507700 & 237468 & 119720 & 117748 \\
2013 & 1241060 & 906793 & 334267 & 215536 & 94644 & 120892 \\
2014 & 1437096 & 956188 & 480908 & 248225 & 118423 & 129802 \\
2015 & 1352564 & 423177 & 929387 & 203383 & 93406 & 109977 \\
2016 & 1352762 & 373757 & 979005 & 177522 & 71612 & 105910 \\
Average & $\mathbf{1 4 9 1 5 6 5}$ & $\mathbf{7 2 9} \mathbf{8 7 9}$ & $\mathbf{7 6 1 6 8 6}$ & $\mathbf{2 5 4 5 2 8}$ & $\mathbf{1 2 9} \mathbf{9 3 5}$ & $\mathbf{1 2 4} \mathbf{5 9 3}$ \\
\hline \hline
\end{tabular}

Source: State Agency of Statistics of R.M. [7] 


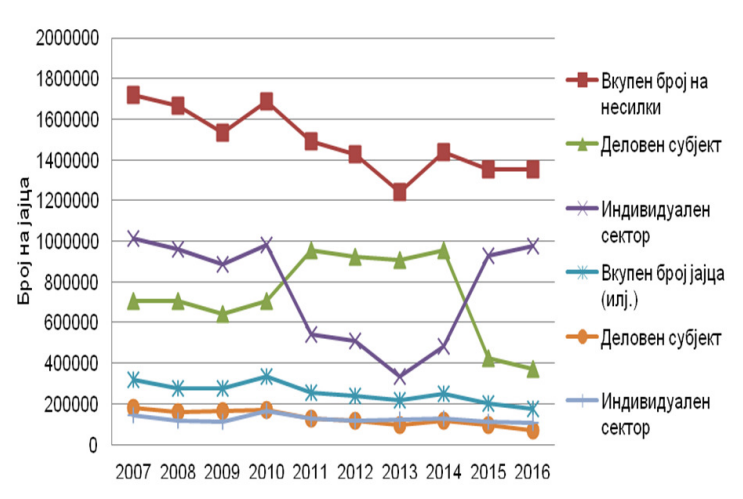

Chart 1. Graphic presentation of the number of layers and the number of eggs produced in the business and individual sectors

The combined average number of produced eggs per layer in the last decade is 167 eggs, and the particular averages per sectors are: 239 in the business sector, and 131 in the individual (Table 3 ).

Table 3

Number of produced eggs per layer in the business and individual sectors

\begin{tabular}{cccc}
\hline \hline Year & $\begin{array}{c}\text { Eggs } \\
\text { per layer }\end{array}$ & $\begin{array}{c}\text { Business } \\
\text { sector }\end{array}$ & $\begin{array}{c}\text { Individual } \\
\text { sector }\end{array}$ \\
\hline 2007 & 187 & 253 & 141 \\
2008 & 166 & 223 & 124 \\
2009 & 179 & 255 & 123 \\
2010 & 199 & 242 & 168 \\
2011 & 171 & 241 & 132 \\
2012 & 166 & 236 & 128 \\
2013 & 174 & 283 & 133 \\
2014 & 173 & 246 & 136 \\
2015 & 150 & 221 & 118 \\
2016 & 131 & 192 & 108 \\
Average & 167 & 239 & 131 \\
\hline \hline
\end{tabular}

Source: State Agency of Statistics of R.M. [7]

The number of laying hens continuously decreases, but their fertility increases because of the acquisition of quality reproductive material. Once having a vast egg production oriented towards export too, after Yugoslavia's dissolution Macedonia lost some big markets whereupon large production facilities became idle, the production dropped and a surplus of employees arose, all this resulting in the closure of many farms and other tried to shift to the production of broilers. Now there are about 10 larger farms (remained of the former huge production facilities) with a capacity of 50,000-100,000 laying hens, and around 50 family-owned farms with a capacity of 3,000-10,000 layers annually. The current production of 250-300 million eggs satisfies the needs of the population, the average annual consumption per capita being 150-170 eggs, while the eggs' prices are stable and satisfactory (for both the producers and the customers). The needs of the foodstuff industry for eggs are big so it feels a shortage in the supply of eggs, for which reason it is necessary to increase the production of eggs, to build plants for packing eggs without shells (only the albumen and the yolk) and for dehydrating eggs (eggs in powder), which would be able to satisfy the needs of the foodstuff industry and would also help solve the problem of surplus of eggs on the market in the summer period when the eggs' price notes a significant drop.

The biggest changes in the poultry production are expected in the sector of egg production where large changes in the way of housing the layers must be done. Namely, the implementation of the regulations about animals' well-being which forbid the housing of layers in conventional cages has been postponed for the year 2020, but without a strong support and involvement of the state in the process of shift towards new rearing systems, even this prolonged deadline won't be of much help to the producers (Milošević et al. [2]).

\section{Production of poultry meat}

The total annual consumption of poultry meat in Macedonia is 23,000-30,000 tons, or 11.5-14.5 kilograms per capita (according to the data supplied by the State Agency of Statistics [7], the annual consumption of poultry meat per capita in the period after 2005 is 11.0 kilograms, which indicates market needs of 22,000 tons a year, while the Veterinarian Administration reports an import of 24,093 tons, a numbers very close to that communicated by FAO) (Table 4).

Poultry meat production for a long period now is brought down to the production of meat only from exhausted laying hens and the rearing of poultry in the rural settlements. The attempts for raising a domestic production of chickens for meat failed for many reasons, so the needs for such meat in Macedonia are satisfied from import. 
Table 4

Production, import and consumption of poultry meat per year

\begin{tabular}{cccccc}
\hline \hline \multirow{2}{*}{$\begin{array}{c}\text { Production } \\
\text { of poultry meat }\end{array}$} & \multicolumn{2}{c}{$\begin{array}{c}\text { Import } \\
\text { of poultry } \\
\text { meat }\end{array}$} & \multicolumn{2}{c}{$\begin{array}{c}\text { Consumption } \\
\text { per capita }\end{array}$} \\
\cline { 5 - 7 } & & \multicolumn{2}{c}{ RM } & EU-25 \\
\hline Year & $(\mathrm{t})$ & Year & $(1000 \mathrm{t})$ & $(\mathrm{kg})$ & $(\mathrm{kg})$ \\
\hline 2007 & 3710 & 2003 & 20.74 & 13.5 & 22.9 \\
2008 & 3524 & 2004 & 25.74 & 15.8 & 22.9 \\
2009 & 3,012 & 2005 & 21.49 & 13.9 & 23.6 \\
2010 & 3,319 & 2006 & 19.69 & 13.2 & 23.6 \\
2011 & 3,236 & 2007 & 30.84 & 19.4 & 23.8 \\
2012 & 1,621 & 2008 & 25.41 & 16.0 & 23.9 \\
2013 & 1,945 & 2009 & 28.78 & 17.3 & 23.2 \\
2014 & 1,801 & 2010 & 25.99 & 17.0 & 23.1 \\
2015 & 2,011 & 2011 & & 16.9 & 22.6 \\
2016 & 1,509 & 2012 & & 17.1 & 22.8 \\
\hline \hline
\end{tabular}

Sources: State Agency of Statistics of R.M. [7];

FAOSTAT - FAO Statistics Division, September 2012 [4]

Namely, the market needs are satisfied with the import of frozen chicken meat (30\% from USA, $18 \%$ from Slovenia, $15 \%$ from South America and China, $13 \%$ from EU). Its low price, despite the poor quality, is decisive for the buyers in choosing it. In the last decade, two attempts were made by some private-owned companies for starting a continuous production of broilers, and the both attempts saw a complete failure. Despite the financial support by the state with 2 denars $/ \mathrm{kg}$ of broiler, these companies were not able to withstand the competition from abroad. The main reason for this failure lies in the expensive feed which consists almost $70 \%$ of the total production costs, the import of almost all the components for the feed mixtures, the absence of modern slaughterhouses for broilers and the low buying power of the population (the annual consumption of chicken meat per capita equals $12 \mathrm{~kg}$, which is $50 \%$ of that in EU countries). If the state helps in solving these problems, there are chances for starting a broiler production, although there is a common belief that the investments in poultry production are expensive endeavour and that very rare are those who can aford organizing an intensive production of eggs or broilers.

Today, the market of poultry meat in $95 \%$ consists of frozen meat from import, on which $€ 30$ million are spent every year, but if the market trends switch to buying quality meat, though at somewhat higher prices (20\%-35\% higher), the fresh poultry meat will suppress the frozen. Having in mind the forecasts and the projections according to the policies for the development of the country designed in the National and IPARD programmes, accompanied by the programme for financial support of the agriculture - a subvention of 30 MKD (EUR 0.47) per broiler in 2011, it is reasonable to expect growth and development of broiler industry in the forthcoming period. If the current level of production is around 2,200 tons per year and satisfies some $7 \%$ of the market needs, when the production starts increasing it is expected the level of $25 \%$ to be achieved in 5 years, or 30\% in 10 years (Kocevski et al. [1]).

The production of ostriches is still supported by the state, and this is inappropriate because it doesn't have a complete production cycle, also appropriate incubators, slaughterhouses, sales network, and so on. The producers are reduced to some enthusiasts in exotic birds because the production is very expensive and the return of the investments is very hard to achieve since for a reliably profitable production all the parts of the slaughtered bird must be used, not to sell live birds as it is the practice now. That's why the financial support for ostrich production ought to be discontinued right away, and the finance to be allocated to some more profitable production.

In general, based on the data about the number of poultry units for a longer period of time, it is very clear that the production of poultry meat has a downward trend, being very unstable and not satisfying the needs of the population. Some of the reasons which led to this situation are these:

- The close-down of the two reproduction centres (for light and heavy material), where parental couples were bred.

- The poor technical and technological condition of the farms and the shut-down of the large production plants.

- Dependence on the import of genetic material and lack of its planning.

- Dependence on the import of components for animal feed and of mineral and vitamin supplements.

- Lack of long-term policy for development of this branch of animal husbandry.

- Haphazard production and poor organization.

- Limited market of poutry products. 
- Incapability for achieving higher competitiveness on the foreign markets and increasing the export of eggs.

- Pronounced instability of the conditions for doing business.

- The appearance of negative attitude towards human nutrition with eggs and the populist reports in the media regarding the appearance of birds' influenza.

\section{DIRECTIONS FOR THE DEVELOPMENT OF POULTRY BREEDING IN THE REPUBLIC OF MACEDONIA IN THE FUTURE}

Of mutual interest for the poultry breeders and the consumers is the modernization of poultry production in the direction of becoming a large-scale mass-production so it could be more competitive on foreign markets. Of course, the goal is to achieve lower production costs in order to stimulate the consumption of poultry meat and eggs, since now the retail price of these products is considered very low as a consequence of the consumers' poor living standard. Also, the goal is to expand the range of the products, not to offer on the market only complete eggs (in shell) or whole chickens for cooking. Macedonia is one of the countries which produce eggs for final consumption but don't have any products made of eggs (eggs in powder, eggs in liquid state, or some semi-finished products for the industry or the consumers). The export of poultry products is necessary, but in the first place a specialized poultry production must be introduced and a better vertical linkage to be made between the producers and the consumers since for achieving higher competitiveness on the foreign markets a continuous delivery and constant, standardized quality of the products are necessary. That's why it is necessary to develop cooperative relationships based on long-term contracts and collaboration.

Another essential issue are the high costs for production of both eggs and meat which, compared to those in some developed European countries, are higher thus leading to poor competitiveness of our producers on those markets. The high price of the inputs in the poultry production is a consequence of the low productivity and the inefficiency of our economy, especially in the sphere of the agriculture.

The rearing of broilers in open range, with natural pastures, dictated by the EU policy for preserv- ing animals' well-being, in combination with the rearing in batteries cages, can be applicable in our rural areas. To this will be added the traditional rearing of turkeys, for whose meat, because of its dietetic properties, there is a large demand by both the consumers and the food industry.

It is considered that poultry breeding, as part of the animal husbandry, is an economic branch which can be revitalized and that it can far more rapidly, for the difference from the other economic branches, reach the European markets.

The realization of the goals of development and the measures of the agrarian policy are limited and preconditioned by the economical and political situation in our country in the recent years. In this period the Macedonian poultry breeding stagnates, and even considerably lags compared with the level and pace of development in the past. Because of this it is necessary to take without any delay certain steps so that the needs of the domestic market for eggs and poultry meat will be satisfied in a higher percentage with products made in the country. For the development of poultry production, the following steps must be implemented in the forthcoming period:

- Elaboration of a programme for revitalization of poultry production in the already existing production facilities through their reconstruction, as well as construction of new, modern facilities with up-to-date, quality equipment.

- Revitalization and rationalization of the traditional extensive or semi-intensive system of rearing poultry, with the goal of producing poultry meat and eggs of special quality.

- Acquisition of live material with high genetic value, through the import of linear hybrids.

- Provision of high-quality feed, vaccines and medicaments, for all the sorts and categories of poultry.

- Orientation of poultry production not towards increasing the number of laying hens, but towards increasing the number of other sorts of poultry - turkeys, ducks and geese.

- Introduction of new, high-productive hybrids which can yield higher amount of meat and eggs also of better quality, as well as new programmes for alternative poultry rearing systems.

- Solving the problems with the slaughterhouse capacities, and introduction of new, smaller, mobile slaughterhouses.

- Introduction of a programme for manufacturing processed poultry products (eggs as powder, 
eggs as liquid, intermediate products and final products of poultry meat).

- Introduction of new production programmes for alternative poultry housing systems which would ease the penetration of the Macedonian poultry products on the European markets.

- Activities focused on finding new markets for the Macedonian poultry products.

- Government support to the producers through different forms of credits and stimulations.

There really are opportunities for the development of poultry breeding in R. Macedonia, and maximal efforts must be made so that the poultry production takes a stable upward trend.

\section{CONCLUSION}

The poultry production in Macedonia in the times of former SFRY enjoyed the reputation of high-developed, large-capacity economic branch, able to provide a large part of the population and business subjects with eggs for final consumption, eggs for production stock, chicks one-day old and pullets, and a substantial part of the production was exported in the neighbouring and other European countries and Near-East countries. After the declaration of the independence, following a very long transition and slow privatization, it came to a rapid decrease of the poultry production, especially in the last decade, so that now Macedonian poultry production suffers a significant lag compared with the level and the pace of the development in the past, and for these reasons urgent steps must be taken in order to achieve the goal of better coverage of the domestic market needs for eggs and poultry meat.

It is considered that the poultry production, as a part of the animal husbandry, is a branch that can be revitalized and that it can far more rapidly than the other branches reach the European markets. It is expected the results of the necessary revitalization steps' implementation to be noticeable in a few years, when the Macedonian poultry production will be able to compete with those of the leading EU countries, under the condition that till then all the economic transition is over, the country's credit rating becomes more solid, and all the organizational problems are solved, first of all in the sphere of organizing appropriate associations based on the interests of all the factors involved in the process of production of poultry meat and eggs.

\section{REFERENCES}

[ 1] Dragoslav Kocevski, Srećko Georgievski, Vuković Vlado, Nikolova Nedeljka: Broiler production in Macedonia, Proceedings International Symposium for Aagriculture and Food, Section 6: Animal Biotechnology, 2015, pp. 1008-1013.

[2] Milosević N., Pavlovski Z. Perić, L.: Present situation, capacities and prospects of development of poultry production in Serbia. Biotechnology in Animal Husbandry, 27 (3), pp. 499-509 (2011).

[3] FAO, FAOSTAT: http://faostat.fao.org, 2010.

[4] FAOSTAT I C FAO Statistics Division 2012 I 09 September, 2012.

[5] Ministry of Agriculture, Forestry and Water Economy (MAFWE), National Agricultural and Rural Development Strategy, 2007,

[6] https://www.zivinarstvo.com/zivinarska-proizvodnja-stan je-perspektive/

[7] MAKSTAT - State Statistical Office of R.Macedonia, Statistic for Animal Husbandry, 2016.

[8] Supić B., Milošević N., Čobić T.: Živinarstvo. Univerzitet u Novom Sadu, Poljoprivredni fakultet, Novi Sad, 2000. 
